\title{
Variables That Take Role on the Consumer Switching Intention toward Minimarket (Study on Indomaret and Alfamart at Kabupaten Jember)
}

\author{
Diah Yulisetiarini ${ }^{1}$, Armanu Thoyib ${ }^{2}$, Rofiaty $^{3}$, Khusnul Ashar ${ }^{4}$ \\ ${ }^{1,2,3,4}$ Faculty of Economics and Business, Brawijaya University, Indonesia
}

\begin{abstract}
This research aims to analyze (a) the role of cost and time on the switching barrier, (b) the the influence switching barrier on the switching intention, and (c) the role of variety seeking behavior on switching intention in the minimarket (i.e. Indomaret and Alfamart) at Kabupaten Jember, Indonesia. The respondents which were the customers who have experienced making shopping transaction at both minimarkets were determined by using purposive sampling method. The research sample is 200 customers of Indomaret and Alfamart. The analysis method used in this research is Partial Least Square (PLS) program. The result demonstrates that cost variable affects switching barrier; besides, time influences switching barrier as well. Yet, variety seeking brings positive but not significant role on switching intention. It implies that there is no direct influence of variety seeking on switching intention; in other words, variety seeking value does not alter the level of switching intention.
\end{abstract}

Keywords: Cost, Switching Barrier, Switching Intention, Time, Variety Seeking

\section{Introduction}

The growth of retail business in Indonesia develops rapidly; this development started in 1960's. The history of retail development in Indonesia can be divided into some stages. The trend is that the each stage runs in a relatively short period. Particularly, it can be concluded that the minimarket business development was started in 1990's; during that time, the retailers that developed rapidly were Indomaret and Alfamart. Retail business even becomes more and more attractive for both domestic and foreign investors to extend their business by taking effort to enter retail market in Indonesia which is perceived to be very potential. The more promising and huge potential of retail business in Indonesia that reaches Rp. 50 trillion per year with the total population of more than 220 million people make the business retail become even more interesting (Ma'ruf, 2005).

Not surprisingly if there are more and more new comers entering retail business market in Indonesia, including foreign retailers. It demonstrates that the future prospect of business retail, particularly for modern retail, in Indonesia is very pleasant. Business retail management in Indonesia has good potential since the market size is huge with enormous population. In every business, an idiomatic expression stating that "ada gula ada semut" always occurs. The retail business practitioners in Indonesia are optimistic that the potential of business retail and franchise will grow favorably as the economics condition gets better as well as the more retail space available. Modern retail business in the minimarket segment will be better and better in its growth. Business retail practitioners are even more vigorous to expand their outlets. This year, the franchisers of Indomaret and Alfamart target 800 new outlets for each (Jakarta, Kompas.com). It can be seen by the more numbers of retail business units both domestic and foreign brands that come up through all over the region.

It encourages the researcher to conduct a research on minimarket modern retail (Indomaret and Alfamart). Consumer goods minimarket recently is about and identical to the rivalry between Indomaret and Alfamart in one particular area of location; if one of the store is built, then the other will always follow. The presence of these minimarkets does not compete merely in between those two stores; the traditional store commonly cannot retain its customers to not switch to Indomaret or Alfamart. The advancement on the number of customers, who go to modern retail store, particularly for customers who live at $\mathrm{t}$ a downtown, demonstrates a trend that those customers prefer to go shopping at modern retail store. Customers experience lifestyle change in shopping; they demand easier, more comfortable, practical, also more choices and more complete goods as they go shopping (Ritel Media Magazine, Edition First Year / July- August 2003). Whenever the income per capita of the population in Indonesia increases, the chance gets even stronger. The presence of modern retail is much more needed by the people to fulfill their needs that always increase as the lifestyle and shopping pattern change. They require comfort, cleanliness, ease, and joyful shopping. The society as the retail consumers is divided into two big groups: traditional retail consumers and modern retail consumers.

The evidence of the better growth and development of modern retail business is on the increasing number of minimarket retails in East Java. It can be observed as the retail business units both domestic and 
foreign brands spread through all over the region. It also happens in Jember Regency as one of the Regencies in East Java. The population density is high and there are a lot of Indomaret and Alfamart retails. There are 41 registered outlets on Industry-Commerce and Energy and Mineral Resources Department of Jember Regency in 2011; while in April to June 2012 the number of the outlets in Jember Regency increases to become 63 outlets of Indomaret and Alfamart. The rapid growth of minimarket retail is also obvious as more and more outlets (Indomaret and Alfamart) are built on each region with high population density such as at Kecamatan (District) level. It becomes the other reason to conduct a research on the modern retail what is so called as minimarket (Indomaret and Alfamart). The benefit of building minimarket in this way is that the society has already known that the place previously was a traditional store (toko or warung) so that it is quite easier to promote new retail store in the same place. The competition among outlets is as high as building new minimarket. The weakness that causes small and independent retail stores experience market share decrease is because they cannot compete with the new retail stores that use minimarket format.

Former research that investigated the role of cost and time on switching barrier was conducted by Anne Findlay and Leigh Spark (2007) ); Keaveney M. Susan (1995); Cengiz and Yayla (2007); Miranda et al., (2005); Colgate, M. And Hedge, R. (2001); Carmen Antón. et al..(2005); Dong-Hee Shin and Won-Yong Kim (2007). The indicator measurement on the cost variable utilized reflective measurement; it obtains a result that there is significant role of cost and time on switching barrier. Meanwhile, Heesup Han et.al. (2010) and Yi-Fei Chung's (2011) research result find that there is no significant influence of cost and time on switching barrier; this research utilized indicator on the time variable by using reflective measurement. Thus, from some empirical evidences, cost and time are the variables that needs further investigating related to their role on switching barrier.

Empirically, research discussing switching barrier and switching intention was made by Dong-Hee Shin and Won-Yong Kim (2007); this research was conducted on customer of the car repair service. The result demonstrated significant influence of switching barrier on switching intention. The conclusion of Dong-Hee Shin and Won-Yong Kim (2007) research mentioned that the indicators of switching barrier and switching intention used reflective measurement. Meanwhile, Heesup Han et.al., (2010) and Yi-Fei Chung (2011) involved post-paid mobile service customers as the research sample in three biggest mobile phone manufacturers in Taiwan. This research result did not show significant influence of switching barrier on switching intention. Based on the analysis result, it concluded that simultaneously there was contribution among switching barrier and switching intention.

Another variable that affects switching intention is variety seeking. Van Trijp et.al (1996) on the research result mentioned that variety seeking did not influence switching intention; further, variety seeking used reflective measurement indicators. The problem on the measurement indicator supports Feiberg et.al's (1996) empirical study which mentioned that switching intention is affected by variety seeking. The research result demonstrated that variety seeking affected switching intention as using reflective measurement.

Based on the description and some empirical studies as well as the occurring phenomenon of Indomaret and Alfamart minimarkets in Indonesia, there is a gap on the research result whether or not switching barrier and variety seeking affect switching intention. The objectives of this research are to analyze and examine the role of cost on switching barrier in minimarket retail; analyze and examine the role of time on switching barrier in minimarket retail; analyze and examine the role of switching barrier on switching intention in minimarket retail; analyze and examine the role of variety seeking on switching intention in minimarket retail.

\subsection{Retail Business Development}

\section{Theoretical Review and Hypotheses Development}

The development of retail sector in Indonesia can be divided into some stages. The trend shows that each stage runs within a short period. The stages of retail industry development (Utami, 2006) are as follow:

\section{Before 1960's era}

This was an era of traditional retail development consisting of independent merchant.

\section{1960's era}

The introduction of modern retail era that had some department stores (mass merchants) as signed by the first retail business launching of Sarinah Building in 1964 at Jl. M.H. Thamrin Jakarta.

\subsection{0 - 1980's era}

The era of supermarket and department store as the sign of modern retail marked with the presence of modern retails such as Matahari, Hero, and Ramayana. In line with the development of supermarket, department store, and shopping center, there were some convenience stores that had 24 hours operating time. The advantage of the 24 hours store is that the near distance with the population residence; even the employees know their customers. The offered commodities commonly are daily needs. Convenience store is just like common store but equipped with better facilities such as air conditioner, cashier machine, and management.

\section{1990's}


The development of convenience store is signed by the bloom of minimarket such as Indomaret. Further, the growth of first class department store as marked with the entrance of Sogo, Metro, and Seibu. Also, there is a cash and carry format by the presence of Makro retail as followed by other local retail with the format like GORO and Alfa.

\section{2000-2010}

This is the era of hypermarket development and e-retailing introduction. This era is symbolized with the entrance of Carrefour with hypermarket format as well as Lippo Shop that introduces e-retailing in Indonesia that is based on the internet utilization. This concept is not yet familiar and hard to be accepted by most Indonesian people who are in habit of making direct purchase. Besides, there is a growth on the franchise retail format.

As the more rapid growth of economics in Jakarta followed by the residence development to the suburban area, then the shopping center begins to reach new regions as the cornerstones of some new residences. Specifically, it can be concluded that the business development of minimarket retail is started in 1990's. Minimarket retail business that rapidly developed on that period was Indomaret and Alfamart. This business retail attracts domestic and foreign investors to expand their business by trying to enter Indonesia retail business market that they perceive to be very potential.

\subsection{Retailing}

Berman and Evans (2001) stated the definition of retailing as follow: retailing consists of two business activities involved in the sale goods and services to consumers of their personal, family or household use; it is the final stage in the distribution process.

This definition is in resemblance with Kotler and Garry (2001) statement who define retailing as all the activities involved in selling goods service directly to final consumers for their personal non business use. Many organizations such as manufacturer, wholesaler, and retailer conduct retail business. Yet, most of the retail businesses that are run by the retailers are the business which its selling comes from retailing itself.

\subsection{Retailing Mix}

Retailing mix is defined as the whole package of goods and service offered by retailers to be sold to the customers. Retailing mix is the factors that mix the tool and technique utilized by the retailers to create value for the customers. Retailing mix is the development of the marketing mix that is more specific and focused on the retail business implementation (Dennis, Fenech, and Merrilees, 2005). In the retail business context, the chosen retailing mixed will define the organization's tactics to reinforce strong position on the target market.

The retail concept is the management orientation that focuses retail to define its needs in more effective and more efficient way. Successful retail must fulfill its customers' needs on the segment that it serves in a better way than its competitors. Retail market is not a particular place where the buyer and seller meet; it is about a group of customers with the same needs and a group of retailers with the similar retail format to fulfill the customers' needs. The retail format definition is a grouping of retail which is based on the particular characteristics such as the offered goods or service, pricing policy, store design, etc.

\subsection{Hypotheses Development}

\section{The Role of Variable Cost on Variable Switching Barrier}

Yi - Fei Chung (2011) and Kem Z.K .Zhang (2009) mentioned that customer is sensitive toward the increasing cost that will influence the switching barrier. The finding of Heesup Han et.al. (2010) demonstrated that high cost does not influence switching barrier. This is the reason to explore and prove the truth. Empirically, this research finding justified the finding of Heesup Han et.al. (2010) which mentioned that high cost brought important influence on the switching barrier. It means that high cost makes high switching barrier (Dong-Hee Shin and Won-Yong Kim, 2007). Based on the former research, it builds the hypothesis 1: Variable Cost affects switching barrier.

\section{The Role of Variable Time on Variable Switching Barrier.}

Time is the transition to obtain consideration and attention on the purchasing process of goods or service. Usually, during the goods or service purchasing process, customers have already considered and measure the time needed to make shopping process related to the store's service/operating hours, time length to reach another minimarket, and time punctuality/preciseness to queue for cashier service. Time plays important role in considering moving or altering to another store/service provider. This variable is built based on the former research from Heesup Han et.al., (2010) and Yi-Fei Chung (2011) which mentioned that customers who consider time to switch is quick or short will increase the switching barrier. Based on the above statements, the hypothesis 2 is: Variable time influences switching barrier. 


\section{The Role of Variable Switching Barrier on Variable Switching Intention}

Switching barrier is the consumer weighting on the chance that is needed if they alter toward the action that prevent the switching intention. Heesup Han et al., (2010), Dong-Hee Shin and Won-Yong Kim (2007) used switching barrier and switching intention variables. Based on the prior research, it builds hypothesis 3 : switching barrier affects switching intention.

\section{The Role of Variable Variety Seeking on Variable Switching Intention}

This variable is built based on the prior research by Van Trijp et.al. (1996) and Feiberg, et.al. (1992). This result is justified by Wilkie's statement (1990) mentioning that the consumer's background to seek variety comes from the curiosity inside the consumer himself. This is the reason of switching intention to occur. Based on the statement above, the hypothesis 4 builds: the higher the variety seeking results on the higher switching intention.

\section{Research Method}

This is an explanatory research or confirmatory research as it aims to analyze the role of one variable to other variable(s) or explain how a variable affects other variable(s). This research is considered as an empirical research that examines the causality test to describe the relationship among variables through hypothesis test. The unit analysis of this research is the customer of Indomaret and Alfamart minimarkets.

\subsection{Sampling Design}

The sample of this research is taken by using non-probability sampling technique; particularly it is purposive sampling method.

The research sample is all of the customers who have experienced in making shopping transaction on minimarket retail business at Indomaret and Alfamart in Jember Regency within some criteria as follow: the respondents are more than 17 years old; purchasing for his/her own need or personal use; making shopping transaction at the minimarket retail for at least three times during the recent three months.

The variable measurement technique utilizes questionnaire as the instrument of data collection from the respondents. The questionnaire of this research uses five stages consisting of strongly disagree, disagree, neutral, agree, and strongly agree. Furthermore, the score of each answer on the questionnaire is ranked as follow: strongly disagree $=1$, disagree $=2$, neutral $=3$, agree $=4$, and strongly agree $=5$.

\subsection{Analysis Method}

This research utilizes Partial Least Square (PLS) as its analysis instruments. PLS is employed since there are exogenous and endogenous variables. Exogenous variables are cost, time, variety seeking. Endogenous variables are switching barrier and switching intention.

\section{Research Findings}

The following is the description of customers response on the research variables that were interviewed during the research.

Tabel 1 Description of Variable Cost (CO)

\begin{tabular}{|c|c|c|c|c|c|c|c|c|c|c|c|}
\hline \multirow{3}{*}{ Indicators } & \multicolumn{10}{|c|}{ Percentage of Customers Responses } & \multirow{3}{*}{ Average } \\
\hline & \multicolumn{2}{|c|}{$\begin{array}{l}\text { Strongly } \\
\text { disagree }\end{array}$} & \multicolumn{2}{|c|}{ Disagree } & \multicolumn{2}{|c|}{ Neutral } & \multicolumn{2}{|c|}{ Agree } & \multicolumn{2}{|c|}{$\begin{array}{c}\text { Strongly } \\
\text { Agree }\end{array}$} & \\
\hline & $\mathrm{f}$ & $\%$ & $\mathrm{f}$ & $\%$ & $\mathrm{f}$ & $\%$ & $\mathrm{f}$ & $\%$ & $\mathrm{f}$ & $\%$ & \\
\hline $\begin{array}{l}\text { Expensive switching cost } \\
\text { (CO.1) }\end{array}$ & 0 & 0.0 & 18 & 9.0 & 68 & 34.0 & 90 & 45.0 & 24 & 12.0 & 3.60 \\
\hline Gifts (CO.2) & 0 & 0.0 & 20 & 10.0 & 67 & 33.5 & 84 & 42.0 & 29 & 14.5 & 3.61 \\
\hline Price Discount (CO.3) & 0 & 0.0 & 17 & 8.5 & 65 & 32.5 & 86 & 43.0 & 32 & 16.0 & 3.67 \\
\hline Average Variable & & & & & & & & & & & 3.63 \\
\hline
\end{tabular}

Source: Primary Data

There are three indicators in CO, namely Expensive switching cost (CO.1), Gifts (CO.2), and Price Discount (CO.3). The highest average response is the third indicator (i.e. CO.3). This means that the customers percieves that the price discount makes them reluctant to switch to other minimarket. 
Tabel 2 Description of Variable Time (TI)

\begin{tabular}{|c|c|c|c|c|c|c|c|c|c|c|c|}
\hline \multirow{3}{*}{ Indicators } & \multicolumn{10}{|c|}{ Percentage of Customers Responses } & \multirow{3}{*}{ Average } \\
\hline & \multicolumn{2}{|c|}{$\begin{array}{l}\text { Strongly } \\
\text { disagree }\end{array}$} & \multicolumn{2}{|c|}{ disagree } & \multicolumn{2}{|c|}{ Neutral } & \multicolumn{2}{|c|}{ Agree } & \multicolumn{2}{|c|}{$\begin{array}{l}\text { Strongly } \\
\text { Agree }\end{array}$} & \\
\hline & $\mathrm{f}$ & $\%$ & $\mathrm{f}$ & $\%$ & $\mathrm{f}$ & $\%$ & $\mathrm{f}$ & $\%$ & $\mathrm{f}$ & $\%$ & \\
\hline $\begin{array}{l}\text { Longer time needed to switch } \\
\text { to other minimarket (TI.1) }\end{array}$ & 0 & 0.0 & 4 & 2.0 & 59 & 29.5 & 106 & 53.0 & 31 & 15.5 & 3.82 \\
\hline $\begin{array}{l}\text { Queueing time in cahsier } \\
\text { (TI.2) }\end{array}$ & 0 & 0.0 & 22 & 11.0 & 71 & 35.5 & 83 & 41.5 & 24 & 12.0 & 3.54 \\
\hline Average Variable & & & & & & & & & & & 3.68 \\
\hline
\end{tabular}

Source: Primary Data

There are two indicators in this variable, namely longer time needed to switch to other minimarket (TI.1) and Queueing time in cahsier (TI.2). The highest average response is the first indicator. This means that the switching requires addition time for moving and shopping to other minimarkets and waste customer time when they moves to other minimarket.

Tabel 3 Description of Variable Switching Barrier (SB)

\begin{tabular}{|c|c|c|c|c|c|c|c|c|c|c|c|}
\hline \multirow{3}{*}{ Indicators } & \multicolumn{10}{|c|}{ Percentage of Customers Responses } & \multirow{3}{*}{ Average } \\
\hline & \multicolumn{2}{|c|}{$\begin{array}{l}\text { Strongly } \\
\text { disagree }\end{array}$} & \multicolumn{2}{|c|}{ disagree } & \multicolumn{2}{|c|}{ Neutral } & \multicolumn{2}{|c|}{ Agree } & \multicolumn{2}{|c|}{$\begin{array}{l}\text { Strongly } \\
\text { Agree }\end{array}$} & \\
\hline & $\mathrm{f}$ & $\%$ & $\mathrm{f}$ & $\%$ & $f$ & $\%$ & $f$ & $\%$ & $\mathrm{f}$ & $\%$ & \\
\hline Cleanliness (SB1) & 0 & 0.0 & 16 & 8.0 & 91 & 45.5 & 64 & 32.0 & 29 & 14.5 & 3.53 \\
\hline Lighting (SB.2) & 0 & 0.0 & 14 & 7.0 & 97 & 48.5 & 63 & 31.5 & 26 & 13.0 & 3.51 \\
\hline Music (SB.3) & 0 & 0.0 & 12 & 6.0 & 107 & 53.5 & 54 & 27.0 & 27 & 13.5 & 3.47 \\
\hline Scent (SB.4) & 0 & 0.0 & 14 & 7.0 & 115 & 57.5 & 48 & 24.0 & 23 & 11.5 & 3.40 \\
\hline Display (SB.5) & 0 & 0.0 & 12 & 6.0 & 108 & 54.0 & 60 & 30.0 & 20 & 10.0 & 3.44 \\
\hline Average Variable & & & & & & & & & & & 3.47 \\
\hline
\end{tabular}

Source: Primary Data

There are five indicators for variable switching barrier terdiri, namely Cleanliness (SB1), Lighting (SB.2), Music (SB.3), Scent (SB.4), and Display (SB.5). The highest average response is the first indicator. This means that the customers considers the cleanliness of minimarket as the important aspect in deciding to switch to other minimarket.

Tabel 4 Description of Variable Variety Seeking (VS)

\begin{tabular}{|c|c|c|c|c|c|c|c|c|c|c|c|}
\hline \multirow{4}{*}{ Indicators } & \multirow{2}{*}{\multicolumn{10}{|c|}{ Percentage of Customers Responses }} & \multirow{4}{*}{ Average } \\
\hline & & & & & & & & & & & \\
\hline & \multicolumn{2}{|c|}{$\begin{array}{l}\text { Strongly } \\
\text { disagree }\end{array}$} & \multicolumn{2}{|c|}{ disagree } & \multicolumn{2}{|c|}{ Neutral } & \multicolumn{2}{|c|}{ Agree } & \multicolumn{2}{|c|}{$\begin{array}{l}\text { Strongly } \\
\text { Agree }\end{array}$} & \\
\hline & $f$ & $\%$ & $f$ & $\%$ & $f$ & $\%$ & $f$ & $\%$ & $\mathrm{f}$ & $\%$ & \\
\hline $\begin{array}{l}\text { The need of variety seeking } \\
\text { (VS.1) }\end{array}$ & 0 & 0.0 & 12 & 6.0 & 58 & 29.0 & 89 & 44.5 & 41 & 20.5 & 3.80 \\
\hline $\begin{array}{l}\text { Immediately seek variation } \\
\text { in other minimarket (VS.2) }\end{array}$ & 0 & 0.0 & 8 & 4.0 & 68 & 34.0 & 95 & 47.5 & 29 & 14.5 & 3.72 \\
\hline
\end{tabular}

Source: Primary Data

There are two indicators in variable, namely The need of variety seeking (VS.1) and Immediately seek variation in other minimarket (VS.2). The highest average response is the first indicator. This means that the customers will seek possible variety when they think that there is possibility to seek variation in other minimarket. 
Table 5 Description of Variable Switching Intention (SI)

\begin{tabular}{|c|c|c|c|c|c|c|c|c|c|c|c|}
\hline \multirow{3}{*}{ Indicators } & \multicolumn{10}{|c|}{ Percentage of Customers Responses } & \multirow{3}{*}{ Average } \\
\hline & \multicolumn{2}{|c|}{$\begin{array}{l}\text { Strongly } \\
\text { disagree }\end{array}$} & \multicolumn{2}{|c|}{ disagree } & \multicolumn{2}{|c|}{ Neutral } & \multicolumn{2}{|c|}{ Agree } & \multicolumn{2}{|c|}{$\begin{array}{l}\text { Strongly } \\
\text { Agree }\end{array}$} & \\
\hline & $\mathrm{F}$ & $\%$ & f & $\%$ & f & $\%$ & f & $\%$ & $\mathrm{f}$ & $\%$ & \\
\hline Possibility to switch (SI.1) & 24 & 12.0 & 78 & 39.0 & 85 & 42.5 & 13 & 6.5 & 0 & 0.0 & 2.43 \\
\hline $\begin{array}{l}\text { Switch as soon as possible } \\
\text { (SI.2) }\end{array}$ & 19 & 9.5 & 82 & 41.0 & 85 & 42.5 & 14 & 7.0 & 0 & 0.0 & 2.47 \\
\hline Average Variable & & & & & & & & & & & 2.45 \\
\hline
\end{tabular}

Source: Primary Data

There are two indicators in variable switching intention, namely Possibility to switch (SI.1) and Switch as soon as possible (SI.2). The highest average response is the second indicator. It means that the major motivation to do switching is the need to move to other minimarket since the current minimarket provides a weak service, offers relatively higher price, and provide a less convinence place.

Based on the figure of inner model test result, it is presented as follow:



Figure 1 direct effect test of inner model

Based on the Table and figure above, the hypothesis test results of the direct effect on the inner model are:

1. Variable Cost affects variable switching barrier

2. Variable time influences variable switching barrier

3. Variable Switching Barrier affects variable switching intention

4. The higher the variety seeking, it will be insignificant for the level of switching intention.

Based on the figure, we can arrange a Table as follow.

Table 6. Test Result of Inner Model Direct Effect

\begin{tabular}{|l|c|c|l|l|}
\hline $\begin{array}{l}\text { Variable } \\
\text { Relationship }\end{array}$ & Coefficient & t-Statistic & p-value & Description \\
\hline CO $\longrightarrow$ SB & 0.340 & 6.158 & 0.000 & Significant \\
\hline TI $\longrightarrow$ SB & 0.357 & 6.507 & 0.000 & Significant \\
\hline SB $\longrightarrow$ SI & -0.436 & 7.180 & 0.000 & Significant \\
\hline VS $\longrightarrow$ SI & 0.015 & 0.194 & 0.846 & Not Significant \\
\hline
\end{tabular}

Data Source: Figure 1 and Primary Data

Cost and time affect switching barrier; and the research finding is able to provide evaluation source to refer in implementing research model related to consumer behavior, particularly in building switching barrier and variety seeking. The finding is also able to provide idea contribution to the Local Government, particularly to the Jember Regency. It is expected to be able to formulate and legitimate Peraturan Daerah (Local Government Regulation) about Indomaret and Alfamart minimarkets establishment as well as other minimarket/ traditional retailer to be able to compete with Indomaret and Alfamart.

\subsection{The Role of Cost Variable on Switching Barrier Variable \\ V. Discussion}

It accepts the hypothesis 1 that cost affects switching barrier. Considering that the inner weight coefficient is positive, it indicates that the relationship of both variables is positive as well. It means that the higher the cost will result on the higher switching barrier. 
Based on some customers that were interviewed by the researcher, they stated that the gift offered by minimarket could add more value/cost to be sacrificed by the costumers during making shopping transaction; and, they would compare the benefit they obtained with all the cost they gave.

This finding is not consistent with Yi - Fei Chung (2011) stating that customers become less sensitive to cost. Empirically, this finding is consistent with the opinion of Heesup Han et al., (2010) that states that a high cost plays an important role in switching barrier. It means that the higher cost causes a higher switching barrier.

This finding shows that the switching cost to other minimarket is very expensive and minimarket gifts makes customers reluctant to switch to other minimarket. The customers perceived that the price discount in minimarket Indomaret and Alfamart on the average becomes a strong switching barrier. This means that minimarket Indomaret dan Alfamart often gives price discount an special price than other minimarket. The customers perceives the influence of cost in the form of price discount and special price on minimarket Indomaret dan Alfamart. The minimarket should provide price discount and special price.

\subsection{The Role of Time Variable on Switching Barrier Variable}

The empirical proof accepts hypothesis 2: time influences switching barrier. As the inner weight coefficient is positive, it demonstrates that the relationship of the both variables is positive. It explains that the higher the time will raise switching barrier up.

From the interview result with the customers, it stated that there was a unique difference on the 24 hours for store service. It means that the customers who are shopping at Indomaret and Alfamart will not take long time, additional time, and do not waste their time. Based on the research result, the dominant indicator that construct time is about punctuality. The opening service hour of Indomaret and Alfamart affects switching barrier. Punctual queue time at cashier at minimarket generate the strongest indicator if it is equal to the what the customers expect. It implies that Indomaret and Alfamart provide better advantage or benefit than their competitors. The customers mentioned that they got additional time benefit to shop at another place, spent more time, and did not waste their time if they switched to another store.

This finding is consistent with Heesup Han et al., (2010) stating that to switch to other minimarket requires some time that will reduce the switching barrier. The time addition and queuing time in cashier plays an important role on switching barrier.

Empirically, this finding is not consistent with the opinion of Yi - Fei Chung (2011) stating that a reltively quick time to move cuases the increase in switching barrier. This is in line with the interviews with the customers stating that there is a unique difference in minimarket that opens for 24 hours. It means that the customers of Indomaret dan Alfamart will not spend a longer time, require no time addition, and avoid the waste time in shopping.

\subsection{The Role of Switching Barrier on Switching Intention}

The test result and empirical proof accept the hypothesis 3: switching barrier affects switching intention. Considering that the inner weight coefficient is negative, and then the relationship among variables is negative as well. It shows that the higher the switching barrier, it will lower the switching intention.

This description is supported by the interview result with the customers of Indomaret and Alfamart who mention that switching barrier are perceived on the cleanliness, lighting, music, scent, and display that are much different; those are the particular uniqueness that differentiates Indomaret and Alfamart from other stores. Further, it also helps the assisted partners such as Kebab Turki and Various Juice as well as Fast Food and Beverage retailers.

This finding is consistent with Heesup Han et al., (2010) and Dong-Hee Shin and Won-Yong Kim (2007) stating that switching barrier significantly influence switching intention. A relatively high switching barrier will cause a lower switching intention. Empirically, this is not consistent with Yi - Fei Chung (2011) stating switching barrier is the main variable to be considered since it will influence directly to switching intention.

Cleanliness is proven to be the dominant factor that provides more value of Indomaret and Alfamart as compared to other store/minimarkets. As the customers are able to perceive the benefit of those factors (cleanliness, lighting, music, scent, and display), they will have low switching intention.

\subsection{The Role of Variety Seeking on Switching Intention}

From the test result, there is no empirical result to accept hypothesis 4: variety seeking affects switching intention. It means that no matter the value of variety seeking, it does not change the switching cost intention.

This finding is not consistent with Van Trijp et al.,(1996) and Wilkie (1990) stating that variety seeking is curiousity of customers after looking some brands of products. This curiousity will cause switching 
intention. Empirically, this finding is consistent with Feiberg, et al., (1992) and Mowen and Minor (2002) stating that variety-seeking refers to the consumers tendency to seek spontaneously a new product. One of reasons in doing this is that the customers is trying the reduce their satiation.

This description supports the interview result conducted by the researcher with the customers of Indomaret and Alfamart; they expressed that making purchase in those minimarkets is indeed a complimentary need with impulsive or spontaneous buying during right and proper situation and condition.

Therefore, it concludes that the need of variety seeking is perceived properly by the respondents. It means that they feel the need to seek for variety; there is a slight role of variety seeking but not significant to the switching intention.

\section{Conclusion}

Cost has significant role on switching. It meets with the customer's perception about cost by comparing the benefit and value that is sacrificed by the customers during making shopping transaction.

The additional time of 24 hours non-stop service is uniqueness; also, queue time at cashier takes important role. Time significantly affects switching intention of the Indomaret's and Alfamart's customers. Switching barrier influences on the low switching intention. Switching barriers are on the cleanliness, lighting, music, scent, and display that are much different as compared to the other minimarkets. It is a particular uniqueness that differentiates this minimarket to another and helps the assisted partners.

Variety seeking does not significantly affect switching intention, since no matter how much the value of variety seeking will not causes any change on the switching intention. Minimarket customers buy something for complementary needs that is impulsively needed as certain and proper condition.

Some of the research limitations are as follow: (a) the research objects is limited to the observation that was conducted within the cross section time range for one single time. It affects the finding related to the causality relationship among the research's variables. (b) The measurement of the research variables uses customers' perception. There will be a trend that the respondents during filling up the questionnaire will always provide good/agree answers which cannot be used to represent the generalization of the research findings. Further research may also consider other research objects such as banking industry or other service industries.

\section{References}

[1] Ma'ruf, Hendri pemasaran ritel (Jakarta: Penerbit PT Gramedia Pustaka Utama, 2005)

[2] Majalah Ritel Media Edisi Tahun I/Juli-Agustus 2003

[3] Anne Findlay and Leigh Sparks, 2007, "Switched": Store-Switching Behaviours “International Journal Of Retail \& Distribution Management" 36(5), 2008, 375-386

[4] Keaveney, S.M, “Customer Switching Behavior in Services Industries: An Exploratory Study", Journal of Marketing, 59, 1995, 71 $-82$

[5] Chengiz, Ekrem dan Erdogan, Y. H., The Effect of Marketing Mix On Positive Worth Mouth Communication: Evidence From Accounting Offices in Turkey, Innovative Marketing, 3, 2007, 4

[6] Miranda, Mario J., Laszio Konya And Inka Havia, 2005. "Shoppers Satisfaction levels Are Not The Only Key To Store Loyalty“ Marketinng Intelellegence Science \& Planning, International Journal of Bank Marketing, 14 (5), 2005, 392-410

[7] Colgate, M. And Hedge, R., "An Investigation Into The Switching Process In Retail Banking Services” International Journal Of Bank Marketing, 19(5) 2001, 201-212

[8] Carmen Anto'n Carmen Camarero and Mirtha Carrero, “ Analysing Firms’ Failures As Determinants Of Consumer Switching Intentions The Effect Of Moderating Factors ”, European Journal of Marketing, 41 (1/2), 2005, 135-158

[9] Dong-Hee Shin and Won-Yong Kim. "Forecasting Customer Switching Intention In Mobile Service: An Exploratory Study Of Predictive Factors In Mobile Number Portability" Technological Forecasting \& Social Change, $\quad$ 75, 2007, 854-874

[10] Heesup Han, Wansoo Kim and Sunghyup Sean Hyun, "Switching Intention Model Development: Role Of Service Performances, Customer Satisfaction, and Switching Barriers In The Hotel Industry" International Journal of Hospitality Management, $X X X-X X X, 2010,11$

[11] Yi - Fei Chuang, "Pull-And-Suck Effects In Taiwan Mobile Phone Subscribers Switching Intentions" Journal Telecommunications Policy, 35, 2011, 128-140

[12] Van Trijp, Hans C.M., Wayne D. Hoyer and J. Jeffrey Inman, "Why Switch?Product Category-Level Explanations for True VarietySeeking Behavior", Journal of Marketing Research, 33(August), 1996, 281 - 292

[13] Feinberg, Fred M., Barbara E. Kahn, and Leigh McAlister, "Market Share Response When Consumers Seek Variety", Journal of Marketing Research, May, 1992, $227-37$

[14] Utami, Christina Widya. Manajemen ritel: strategi dan implementasi ritel modern (Jakarta: Penerbit Salemba Empat, 2006)

[15] Berman,H.W. and Joel R.Evans Retail management a strategic approach (USA: Prentice Hall International Inc, 2001)

[16] Kotler, Philip, and Gary Amstrong Principles of marketing nineth edition (New Jersey: Prentice Hall Inc, 2001)

[17] Dennis, Charles, Tino and Bill Merrilees, "Sale The 7 Cs : Teaching /Training Aid For The (E-) Retail Mix, International Journal Of Retail \& distribution Management, 33 (3), 2005, 179-193

[18] Wilkie Consumer behavior (New York: John Willey And Son, Second Edition 1990) 